\title{
施設栽培(トマト)における収穫作業の省カ化 についで
}

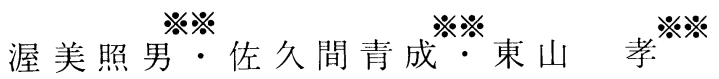

On the Labour Saving of Harvesting for Vegetables in Green house Culture.

Teruo ATSUMI, Harushige SAKUMA ${ }^{\dagger}$ and Takashi HIGASHIYAMA ${ }^{\dagger}$

\section{1 緒言}

施設栽培では，作物がより生育しやすい環 境に制御するため, 暖冷房, 保温, 換気, 炭 酸ガス施用, 灌水などの装置が実用化されて らる。しかしてれらの装置によって制御され た施設内は外気との環境条件の差が大きく， 労働の場として好ましくないしとは周知のと おりである。しかもそてでの栽培方法は労働 集約型であるため, 筆者らの調査したトマト の $10 \mathrm{a}$ 当たり労働時間は $900 \sim 1,500$ 時間が 投下されていたが，そのらち収檴調製作業は $50 \%$ 前後に達していた。したがって収穫作 業の省力化壮生産性の向上を図るらえで, 重 要な手段の一つであると考えられた。

このととに関しては，すでに小嶋ら 6 ），小 堀 $5^{3}$, 中村, 岐阜農試など多くの報告が見ら れる。これらの報告は, 省力化は作業の精度 を落とすととなく，人間の行ら労働を機械に 代行させるととを前提とし, 収椎作業の省力 化は運搬作業を対象にすべをであることを指 摘している。乙のよらな見地から, 小嶋らや 岐阜農試ではバッテリ一式の自走運搬車の開 発を行ったが, 乗用化についての検討は行っ ていない。をな堀らは歩行型のバッテリー カーと慣行のカゴ及びバケッとによる，運搬 手段を異にした収檴作業の労力を比較した結果,
大面積の収穫にはバッテリ一・カーの利用が効 果的であるとしながらも，常に著しい高能率化， 快適化が認められるわけでないととを報告して ら。

筆者らは収穫運搬作業の合理化, 快適化は, 作業者と作物との相対位置を作業者に有利にす るととによって進められるとの考え方に基づい て，運搬車を乗用型に改良するととを企画し， そのために必要な操縦装置, 緩発進装置, 座席 等を装備し, かつ荷台面積を十分確保し, 歩行 操縦も可能なバッテリー・カート（以後乗用自 走車と称する) を試作した。

ここではこの采用自走車を実用化するに当た っての知見を得るため, トマトの収檴作業にお ける作業能率について, 手押四輪車を比較対象 にして検討したので，その概要を報告する。

\section{2 試験方法}

供試機の事用自走車と手押四輪車の主な仕様 は第 1 表に，またその構造は写真 1 亿示した。

供試作物のトマト (米寿) は 9 月 1 日には種 し, 10 月15日に定植した。栽植様式は, らね 間通路 $80 \mathrm{~cm}$ を含めた幅 $180 \mathrm{~cm}$, 長さ $25 \mathrm{~m}$ の ねへ, 株間 $45 \mathrm{~cm}$, 条間 $60 \mathrm{~cm}$ の間隔に 2 条植と した。をた栽培法は 5 段果房の上位 2 枼を残し て摘心した。

調査項目は，収穫作業時間は各果房ごとに乗 
第 1 表 供試車の主な仕様

\begin{tabular}{|c|c|c|}
\hline & 乗用自走車 & 手押沉輪車 \\
\hline 外形寸法巾 $\times$ 長 $\times$ 高 & $55 \times 100 \times 32 \mathrm{~cm}$ & $44 \times 80 \times 10 \mathrm{~cm}$ \\
\hline 荷台寸法巾 $\times$ 長 & 前後部之 $55 \times 40 \mathrm{~cm}$ & $44 \times 70$ \\
\hline 重 & $97 \mathrm{~kg}$ & $6.3 \mathrm{~kg}$ \\
\hline 最 大積 載 重 & $150 \mathrm{~kg}$ & $80 \mathrm{~kg}$ \\
\hline 走 行 速 度 & $2.3, \quad 3.8 \mathrm{Km} / \mathrm{h}$ & - \\
\hline モ一 - - (出力) & $12 \mathrm{~V}, \mathrm{DC} 250 \mathrm{~W}$ & - \\
\hline $\begin{array}{lllll}\text { バ } & ッ & \text { テ } & リ & -\end{array}$ & $12 \mathrm{~V}, 100 \mathrm{AH}$ & - \\
\hline
\end{tabular}

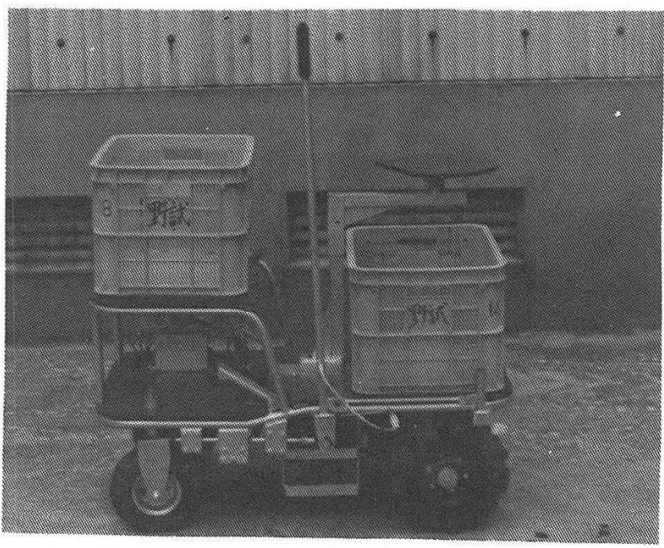

乗用自走車

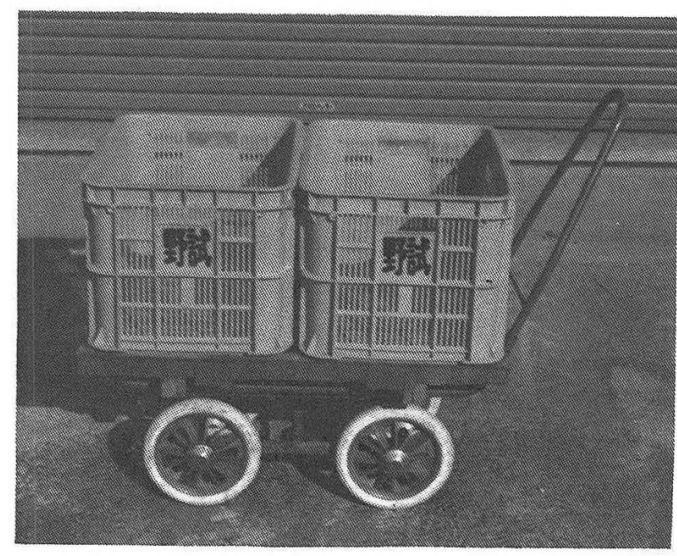

手押四輪 車

写真 1 側面から見た供試車

用自走車と手押四輪車とについて, 作業者がう ね間通路に沿って両側の果実を収檴しながら進 み，そのらねの収椎在終えると車在旋回して次 のらね間に移り, 再び収檴しつつ元の位置まで もどる時間をデジタルストップウオッチで計測
した。をた作業中における作業者の脈はく数の 経時変化はテレメーターポリグラフを用いて測 定した。

被験者は 37 歳の男子で, 身長 $166 \mathrm{~cm}$, 体重 $67 \mathrm{~kg}$ であり,施設栽培に扫りる果菜類の栽培管 理作業の経験は比較的豊富である。

\section{3 結果}

\section{1) 収穫作業時間}

運搬方法㓯にした果房段位別の収穕作業時 間は第 2 表に示した。第 2 表における各果房段 位ごとの収穫果数は, その段位における収穫谪

第 2 表 段位別の収穫果数と所要時間

\begin{tabular}{|c|c|c|c|c|c|c|c|}
\hline \multirow{3}{*}{\multicolumn{2}{|c|}{$\begin{array}{c}\text { 調 } \\
\text { 査 } \\
\text { 期 } \\
\text { 日 }\end{array}$}} & \multirow{3}{*}{$\begin{array}{l}\text { 収 } \\
\text { 穫 } \\
\text { 段 } \\
\text { 位 }\end{array}$} & \multirow{3}{*}{$\begin{array}{l}\text { 着 } \\
\text { 果 } \\
\text { 位 } \\
\text { 置 }\end{array}$} & \multicolumn{2}{|c|}{ 乗用自走䡩 } & \multicolumn{2}{|c|}{ 手押四輸車 } \\
\hline & & & & 収穫/うね & 時間／個 & 収穫/らね & 時間/個 \\
\hline & & & & 果数時間 & 收穫彩果 & 果数時間 & 収穫採果 \\
\hline 月 & 日 & 段 & $c m$ & 個 & 秒 秒 & 秒 & 秒 秒 \\
\hline 1 & 18 & 1 & 71 & $266 \quad 1402$ & $\begin{array}{ll}5.3 & 5.0\end{array}$ & 3131203 & $\begin{array}{ll}3.8 & 3.7\end{array}$ \\
\hline 2 & 15 & 2 & 90 & $447 \quad 1563$ & $\begin{array}{ll}3.5 & 3.3\end{array}$ & 4631546 & $\begin{array}{ll}3.3 & 3.2\end{array}$ \\
\hline 2 & 22 & 3 & 118 & $546 \quad 1790$ & $\begin{array}{ll}3.3 & 3.2\end{array}$ & 5021761 & $3.5 \quad 3.4$ \\
\hline 3 & 7 & 4 & 147 & 5111730 & $\begin{array}{ll}3.4 & 3.2\end{array}$ & $516 \quad 1745$ & $\begin{array}{ll}3.4 & 3.3\end{array}$ \\
\hline 3 & 15 & 5 & 172 & 4081433 & $\begin{array}{ll}3.5 & 3.3\end{array}$ & $510 \quad 1941$ & $\begin{array}{ll}3.8 & 3.7\end{array}$ \\
\hline
\end{tabular}

期の果実が最も多いと判断した日に調査を実施 したが，果房段位ごとの差は大をく，とくに乗 用自走車の 1 段と 3 段果房とでは倍以上の開を があり，1個体当たりでは 1 段果房の 1.1 個に 対して 3 段果房では 2.4 個であった。収穕作業 を構成する要素在捜す，採る，運ぶ動作次分解 した場合，果実 1 個当たりの所要時間は，15 水の収檴果数の多少に支配される度合が一般的 に大をいと考えられる運ぶ動作とその影響が少 ない捜す，採る動作に分けられる。このため果 実 1 個当たりの所要時間は全要素を含めた収穫 時間之, それから運ぶ動作の時間を除らた採果 時間とを示した。

乘用自走車による1個当たりの収穫時間は, 1 段果房では 5.3 秒であったが, 2 〜段果房 は3.3〜3.5杪で, 両者の間には 2 秒近くの差が あった。手押四輪車では 1,5 段果房が 3.7 秒で, これは $2 \sim 4$ 段果房の3.4秒よりもやや多加 た。採果時間は, 乗用自走車では果数が極端に 少なかった 1 段果房が 0.3 秒, 他の果房段位が 
$0.1 \sim 0.2$ 秒，手押四輪車では各果房段位とも 0.1 秒, いずれも収穫時間より少なかった。

一方両運搬方法における果房段位ごとの比較 は，1段果房では手押四輪車が，5段果房では

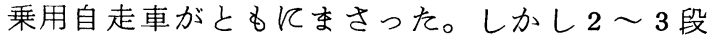
果房では運搬方法による差は認められなかった。

2）作業の快適性

収穫作業沈数作業の快適性は, 被験者の 脈はく数の経時変化をテレメーター・ポリグラ フにより無線方式で計測し，作業を始める前の 安静時の脈はく数に対する作業継続中の脈はく 数の増加割合 (増加率) を指標にして推定した。

各果房段位の作業時脈はく数の経時変化は第 1 図に, また脈はく数増加率及び休息時間は第 3 表に示した。第 3 表によれば，各果房段位に

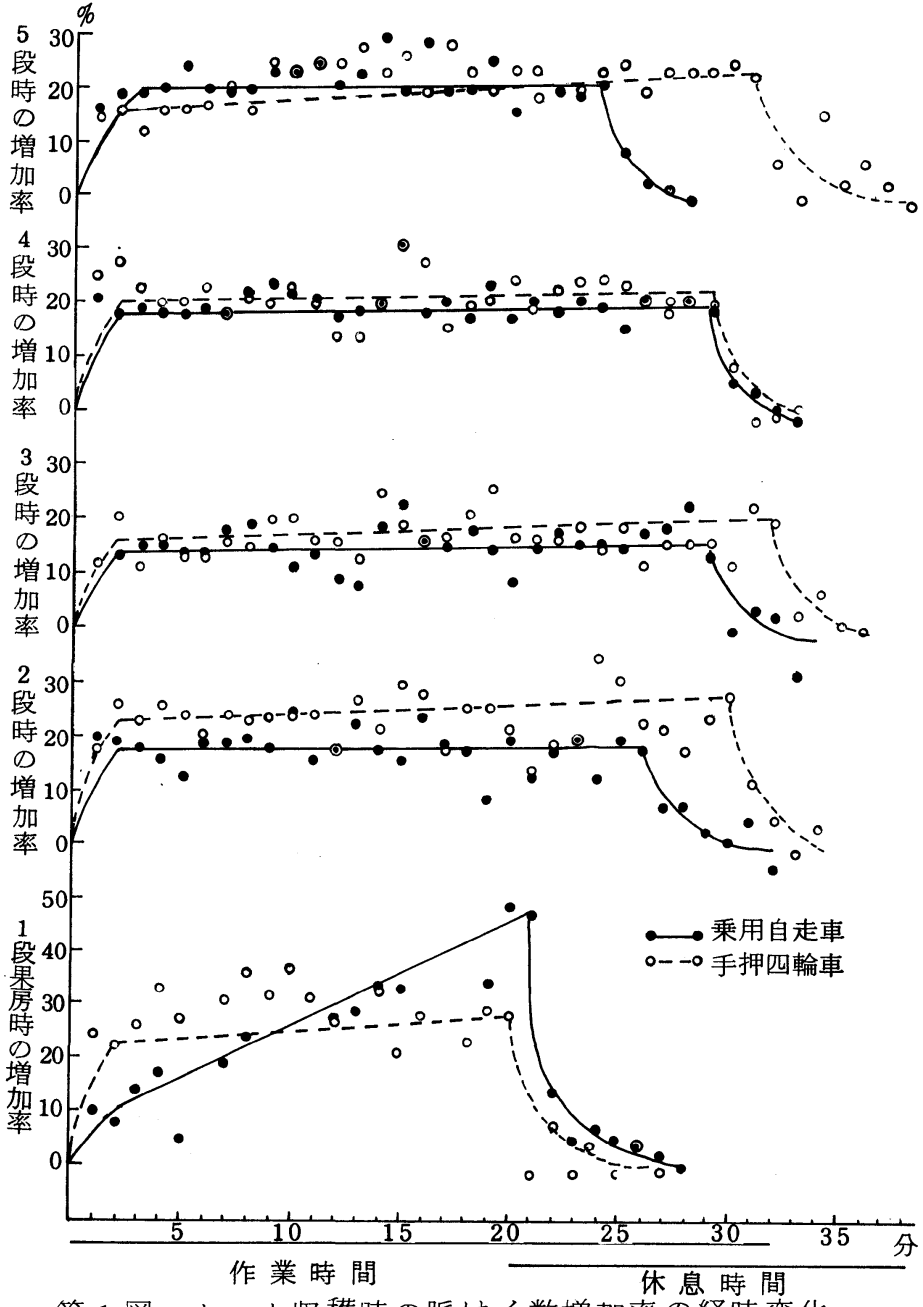

第 1 図卜マト収穫時の脈はく数増加率の経時変化
第 3 表 脈はく数増加率及び休息時間

\begin{tabular}{|c|c|c|c|c|c|}
\hline \multirow{3}{*}{$\begin{array}{l}\text { 収 } \\
\text { 穫 } \\
\text { 段 } \\
\text { 位 }\end{array}$} & \multicolumn{2}{|c|}{ 作業時の脈はく数増加率 } & \multirow{2}{*}{$\begin{array}{l}\text { 作業 } \\
\text { 継続時間 }\end{array}$} & \multirow{2}{*}{\multicolumn{2}{|c|}{$\begin{array}{l}\text { 作業終了後 } \\
\text { 休息時間 }\end{array}$}} \\
\hline & 開始直後 & 終 了時 & & & \\
\hline & 乗用手押 & 乗用手押 & 乗用手押 & \multicolumn{2}{|c|}{ 乗用手押 } \\
\hline 段 & $\% \quad \%$ & $\%$ & 分 & 分 & 分 \\
\hline 1 & $10 \quad 23$ & $48 \quad 28$ & 2120 & 7 & 6 \\
\hline 2 & $18 \quad 23$ & 1928 & $26 \quad 30$ & 6 & 4 \\
\hline 3 & $14 \quad 16$ & $16 \quad 21$ & $29 \quad 32$ & 4 & 5 \\
\hline 4 & $18 \quad 20$ & $20 \quad 23$ & $29 \quad 29$ & 4 & 4 \\
\hline 5 & $20 \quad 16$ & $21 \quad 24$ & $24 \quad 31$ & 4 & 7 \\
\hline
\end{tabular}

よって収穫果数が異なったので，作業の継続時 間は，1段果房では両運搬方法とも20 分間で あったが，2〜 5 段果房では $25 \sim 30$ 分間を要 した。また脈はく数の増加率は, 1 段果房では 手押四輪車が作業開始直後（2 分後）飞 $23 \%$ まで急上昇したが, その後の増 加は緩慢で，作業 終了時には $28 \%$ であったのに対し, 乗用 自走車では開始直後は $10 \%$ で あったが, その後も高い割合で 增加しつづけ, 終了時には 48 \%に達した。2 段果房では, 手 押四輪車の増加率は 1 段果房と 同じ経過を示したのに反し，乗 用自走車は作業直後に $18 \%$ 本 で急上昇したが，作業終了時も $19 \%$ あ゙あ，作業中における 増加率の上昇は極めて少なかっ た。乗用自走車におけるとのよ ら㞭傾向は $3 \sim 5$ 段果房につ々 ても認められ，いずれす作業開 始直後之終了時之の増加率の差

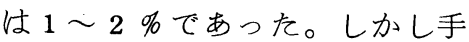
押四輪車の $3 \sim 5$ 段果房ではと の差が大をくなる傾向が認めら れ，とくにそれは 5 段果房が顕 著であった。作業終了後, 安静 時の脈はく数にまで回復するの 飞要した時間（休息時間）は， 萧用自走車では $1 ， 2$ 段果房収 穫時が $6 \sim 7$ 分, $3 \sim 5$ 段果房 は4 分間であったが，手押四輪 
車では, 1,5 段果房が $6 \sim 7$ 分， $2 \sim 4$ 段果房 は $4 \sim 5$ 分間であった。

以上の結果をもとに, 果房段位別の収穫作業 能率を求め第 4 表に示した。第 4 表によれば, 休息率は両運搬方法とも 3 段果房が最も低く,

第 4 表 果房段位別の收穫作業能率

\begin{tabular}{|c|c|c|c|c|c|c|c|c|c|c|c|c|}
\hline & & \multirow{2}{*}{$\begin{array}{l}\text { 単 } \\
\text { 位 } \\
\end{array}$} & 乗 & 用 & 自 & 走 & 車 & 手 & 押 & 四 & 輪 & 車 \\
\hline & & & 1 & 2 & 3 & 4 & 5 & 1 & 2 & 3 & 4 & 5 \\
\hline 休 & 息 & 率 \% & 34.7 & 26.9 & 13.8 & 17.2 & 20.8 & 35.0 & 24.1 & 15.6 & 24.1 & 25.8 \\
\hline 実 & 働 & 率 \% & 74.1 & 78.7 & 87.8 & 85.5 & 82.6 & 74.1 & 80.6 & 85.5 & 80.6 & 79.4 \\
\hline & 婸作業 & 率 \% & 98.8 & 97.8 & 98.1 & 98.0 & 97.6 & 98.8 & 98.1 & 98.4 & 98.2 & 98.4 \\
\hline & 作 業 & 量 $k g / h$ & 14.5 & 15.7 & 176 & 203 & 188 & 182 & 156 & 158 & 182 & 17.8 \\
\hline & 業 & 率 \% & 73.2 & 72.0 & 86.0 & 83.8 & 80.6 & 73.2 & 79.1 & 84.1 & 79.7 & 78.1 \\
\hline
\end{tabular}

下げた時のひじ(时) 高さとは $35 \sim 40 \mathrm{~cm}$ 差 があった。このため被験者は採果のつど，膝や 腰を曲げなければならなかったととの影響が収 穫時間を多くしたと考えられ，とくに膝が使え ず腰を曲げるだけで低位置の果実に接近しなけ

ればならなかった乗 用自走車にその影響 が顕著にあらわれた と推察された。また 5 段果房では採果位 置が被験者の身長と ほ汸同じであったか ら, 手押四輪車では 採果姿勢に無理が生
それより上下の果房では高くなった。しかしそ の程度は乗用自走車では $1 ， 2$ 段果房が高かっ たのに対し, 手押四輪車は $1 ， 5$ 段果房が高か った。したがって実働率は

\section{$100 \div($ 休息率 +100$)$}

から求められるので, 当然のととながら休息率 之同じ傾向であった。また有効圃場作業効率は

固場作業量 $(\mathrm{a} / \mathrm{hr}) \div$ 有効作業量 $(\mathrm{a} / \mathrm{hr}) \times 100$ から求めたが, 運搬方法や, 果房段位に上る差 は小さくいずれも $98 \%$ 前後であった。てのた め実働率と有効圃場作業効率との積で表される 実作業率（拘束時間の中で占める実作業時間の 比率 ) 飞も休息率の寄与する割合が高く, 両運 搬方法飞よる 1 段果房や乗用自走車の 2 段果房 及び手押四輪車の 5 段果房が低かった。

\section{4 考察}

\section{1）収穫時間}

本試験における被験者と果実の着果位置との 相対位置は第 2 図に示したょうに, 運搬方法の 違いによる差は極めて小さかった。をた運搬車 の載貨量はともに80 kgであった。したがって 被験者がひざ(膝) や腰を曲げたり, 背伸びを しなくても容易に果実に接近するてとがでをた $2 \sim 4$ 段果房では, 果房段位や運搬方法などの 違いが収穫作業時間に及ばす影響は極めて少な かった。しかし1段果房では着果位置は地上高 $70 \mathrm{~cm}$ 前後であったから, 被験者が自然に手を
じやすかったのに反して, 乗用自走車は車を踏 み台として利用でをるので， $2 \sim 4$ 段果房と同 じ姿勢で採果するととが可能であったために, 両運搬方法の間に差が生じたと考えられた。

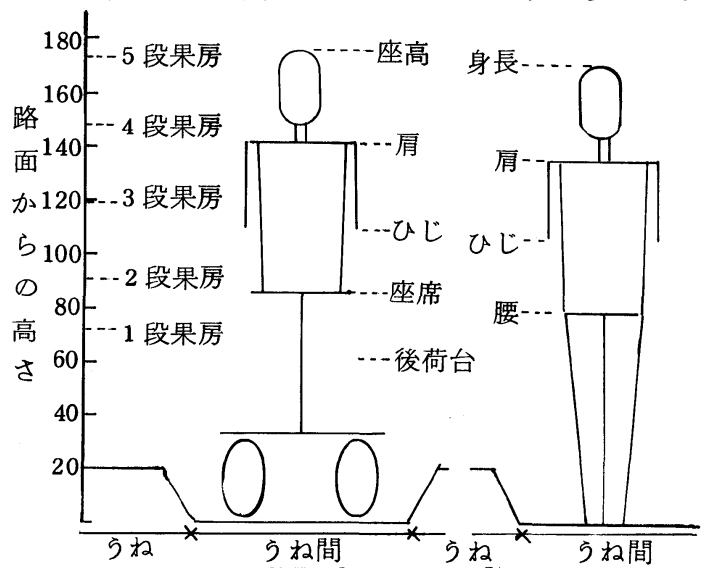

第 2 図被験者と果房段位との相対的高さ

2) 作業の快適性

各調査時における施設内の気温は $20{ }^{\circ} \mathrm{C}$ 内外 湿度は70\%前後であった。これを小堀）が作業 快適性のための条件として設定した值にあては めると, 気温は快適域 $\left(17 \sim 27^{\circ} \mathrm{C}\right)$ 亿, 湿度は 不快域 ( $65 \sim 80 \%)$ 飞属した。しかし作業強度 は R. M. R が 2 程度の軽作業 8 ) 飞属する(快適 域 $0 \sim 4$ ) と判断されるので, 比較的低温下で の作業であったととを考慮すれば, 高湿が被験 者の脈はく数増加率に及漂した影響は少なかっ たと考えられた。したがって各調査時の増加率 の差は収檴時の運搬手段によって規制された， 
乗用と歩行との違い及び採果時の作業姿勢など の影響にょるものと判断して差しつかえがない であろう。

このような理由から, 乗用自走車の1段果房 の増加率が時間の経過飞比例して上昇したのは 前述したように着果位置が低かったため，採果 時には被験者の頭部が腰よりも低くなることが 多加たととの影響によるものと考えられた。 一方手押四輪車の 5 段果房に和ける作業開始直 後と終了時との増加率の差が， $1 \sim 4$ 段果房の それより高くなったのは, 小堀”が作業点の高 さと作業者脈 はく数增加率との関係加ら推定し を作用点の快適域 $(70 \sim 150 \mathrm{~cm})$ の上限加着 果位置が $20 \mathrm{~cm}$ 高位にあったととの影響による ものと考えられた。

$3)$ 結 言

以上のととから小嶋”) ${ }^{7}$ 以゙ッッテリー・カー を使用しても作業者の動作が単純化されるとは レえないので収穫作業能率は向上しない”との 指摘は，果実つ採果位置が作業者の適作業域に あり，汃運搬車の載貨量が人力, 動力車とも 同じである場合にいえるととと考えられた。し かし果実は適作業域外任着果しているととがあ るので, 上り適作業域が広くなる乗用, 歩行操 車が可能な運搬車の利用は収穫作業能率の向上 に役立つと考えられた。

\section{5 摘 要}

1) 筆者らが開発試作した莱用型自走運搬車 の実用化を図るため, 収穫作業における作業能 率を手押四輪車と比較検討した。

2）供試作物のトマトは 5 段栽培とした。

3 ）収檴時間は, 乗用自走車の 1 段果房や, 手押四輪車の $1 ， 5$ 段果房では多かったが，他 の果房段位では差が少なかった。

4) 脈はく数増加率は手押四輪車による場合 が全般的に高かったが，兼用自走車の 1 段果房 はとくに高かった。
5） 1 段果房を除けば乗用自走車は休息率が 低く，実作業率が高かったので，作業快適化の 効果は高羊判された。

6 ) 本自走車は歩行操車のための装置も設備 してあるので, 以上の結果から収檴作業能率の 向上飞役立つととが確かめられた。

\section{6 引用文献}

1) 渥美照男, 東山孝, 佐久間青成 (1977) : 施設, 栽培(トマト) に和ける作業の省力化に ついて野菜試施設栽培年報, $3,33 \sim 36$

2）——佐久間青成，東山 孝（1978）: 施設栽培に水ける栽培管理作業の省力化に関す る研究，I 乗用型自走運搬車の改良につんて， 野菜試験場報告，A 4，103１18

3）小堀乃, 倉田久治, 古谷 正, 中西 修, 岐阜農試 (1975)：農作業の人間工学的研 究, (1) 卜マ卜收穫作業江関する試験, 野菜試栽 培部年報, $2,67 \sim 70$

4 ）—(1968）：農作業における人間工 学〔2〕，農業及び園芸，43，5，749〜754

5 )- (1977): 農作業の人間工学的研 究, (4)施設内作業の作業域闺関する試験, 野菜 試栽培部年報, 4, 103 106

6 ) 小嶋和雄, 緒方一男, 池見隆男, 土居栄 城, 大久保疜一 (1972) : ビニールハウス内運 搬の機械化江関する研究（第 4 報），農業機械 学会誌， $34 ， 2 ， 157 \sim 163$

7 ） (1975)：プラスチック内作業の 人間工学的研究一機械化の考方方一。農業機械 学会誌, $37,3,420 \sim 424$

8) 中村宏 $(1975)$ ：ビニールハウス内に 和けるキュウリ収穫作業の合理化に関する研究。 神奈川県総合研究所報告 $115,71 \sim 81$

9 ）岐阜県農業試験場（1973）：多目的装置 - 機械の利用開発江関する試験 (N) 防除・運 搬機械，施設園芸の装置化による作業の省力に 関する試験成績書， $32 \sim 51$ 